[Chem. Pharm. Bull.

35( 4$) 1523-1530(1987)]$

\title{
Potentiation of Host-Mediated Antitumor Activity by a $\beta$-Glucan Derived from Mycelia of Cochliobolus miyabeanus
}

\author{
Hiroaki Nanba* and Hisatora Kuroda \\ Department of Microbiology, Kobe Women's College of Pharmacy, \\ Motoyama, Higashinada, Kobe 658, Japan
}

(Received August 27, 1986)

\begin{abstract}
A polysaccharide (6-branched $\beta$-1,3-glucan, As-I) extracted from mycelia of Cochliobolus miyabeanus (Ascomycetes) inhibited the growth of against mouse syngeneic tumors $(80 \%$ inhibition of MM-46 carcinoma and 30\% inhibition of IMC carcinoma) when injected i.p. $(0.1 \mathrm{mg} / \mathrm{kg} / \mathrm{d})$. As-I enhanced the phagocytosis of syngeneic tumor cells by macrophages about 1.5 times, and the production of superoxide anion about 1.2 times. As-I also activated natural killer cells and increased the activity of killer $\mathrm{T}$ cells about 1.3 times.
\end{abstract} beanus

Keywords_-antitumor glucan; macrophage; natural killer cell; $\mathrm{T}$ cell; Cochliobolus miya-

As described in a previous paper, ${ }^{1)}$ a $\beta$-glucan having 1,6 branches, isolated from mycelia of Cochliobolus miyabeanus (Ascomycetes), caused about $50 \%$ growth inhibition of allogeneic tumors when injected at the dose of $0.5 \mathrm{mg} / \mathrm{kg}$ for 9 consecutive days. When intraperitoneal macrophages of mice were treated with this glucan either in vitro or in vivo, the spreading rate and phagocytic activity were increased. ${ }^{2)}$ Activated macrophages, cytotoxic cells, natural killer (NK) cells, and killer cells have important roles in tumor immunity. As found for lentinan ${ }^{1,2)}$ antitumor glucans activate multiple sites in the cellular immune systems. In this paper, the antitumor action of As-I (6-branched $\beta$-1,3-glucan) on syngeneic tumors was investigated, and the mechanisms of action on macrophage, cytotoxic cells, and NK cells were also examined.

\section{Materials and Methods}

Preparation of Polysaccharide (As-I) - The polysaccharide As-I was prepared from mycelia of Cochliobolus miyabeanus (ATCC 38724, Ascomycetes) as described previously. ${ }^{1}{ }^{1}$

Animals-Male ICR (4 weeks), C3H (6 weeks), CDF 16 weeks) and BALB/C (5 weeks) mice were purchased from Japan Charles River Ltd. After acclimation for one week, mice were used for tests.

Tumor Growth Inhibitory Effect-MM-46 tumor cells $\left(2 \times 10^{6}\right)$ were transplanted s.c. into male C3H mice (7 weeks), IMC-carcinoma cells $\left(2 \times 10^{6}\right)$ into male $\mathrm{CDF}_{1}$ mice $\left(7\right.$ weeks), and Meth-A fibrosarcoma cells $\left(1 \times 10^{6}\right)$ into male BALB/C mice (6 weeks) in the axilla. After $24 \mathrm{~h}, 1 \mathrm{mg} / \mathrm{kg} / \mathrm{d}$ of As-I was injected i.p. daily for $10 \mathrm{~d}$. On the $25 \mathrm{th}$ day after tumor transplantation, the solid tumor was extirpated and weighed to obtain the tumor growth inhibition ratio (TIR) according to the method described in the previous paper. ${ }^{2}$

Collection of Macrophages in Peritoneal Cavity_-Peritoneal cells were obtained by washing with Hanks' solution from the peritoneal cavity of mice killed by vertebral dislocation. After centrifugation at $1200 \mathrm{rpm}$ for $10 \mathrm{~min}$, the precipitated cells were collected and adjusted with RPMI-1640 medium to $1 \times 10^{6} \mathrm{cells} / \mathrm{ml}$. These cells were pipetted $(1.5 \mathrm{ml})$ onto a plate and cultured at $37{ }^{\circ} \mathrm{C}$ for $2 \mathrm{~h}$ in a $5 \% \mathrm{CO}_{2}$ atmosphere in air; $\mathrm{M} \phi$ were adsorbed selectively on the plate wall. The non-adherent cells were eliminated by washing 3 times with Hanks' solution.

Measurement of Superoxide Anion (SOA)_As-I $(50 \mu \mathrm{g})$ was injected i.p. into male ICR (5 weeks), C3H (7 weeks) and BALB/C (6 weeks) mice daily for $5 \mathrm{~d}$. On the 5 th day after completion of administration, $\mathrm{M} \phi$ were collected and SOA was measured according to the method of Ito et al. ${ }^{3)}$ Then $1.5 \mathrm{ml}$ of phosphate buffered saline (PBS) containing $10 \mathrm{~mm}$ glucose, $80 \mathrm{~mm}$ ferricytochrome $\mathrm{c}$ and $0.2 \mathrm{mg} / \mathrm{ml}$ of opsonized zymosan was added to 
adherent $\mathrm{M} \phi$ on the plate. After centrifugation at $3000 \mathrm{rpm}$ for $5 \mathrm{~min}$, the supernatant was collected in an ice-chilled test tube and the absorbance at $550 \mathrm{~nm}$ was measured. On the other hand, $1 \mathrm{ml}$ of $0.5 \%$ sodium dodecyl sulfate (SDS) was added to the precipitated cells, and after standing for $5 \mathrm{~min}$, the cells were well dispersed. The amount of ferricytochrome $\mathrm{c}$ was obtained from the absorbance at $550 \mathrm{~nm}$, based on $\Delta E 550=2.1 \times 10^{4} \mathrm{M}^{-1}$, and released SOA per unit protein was calculated.

Opsonization of Zymosan ${ }^{4}$ —__ Zymosan A was adjusted with PBS to $10 \mathrm{mg} / \mathrm{ml}$, boiled for $1 \mathrm{~h}$, washed 3 times, and readjusted with PBS to $50 \mathrm{mg} / \mathrm{ml}$. Human serum (4 volumes) was added to 1 volume of zymosan $(50 \mathrm{mg} / \mathrm{ml})$, and the mixture was incubated at $37 \mathrm{C}$ for $30 \mathrm{~min}$. Zymosan was collected by centrifugation, and $10 \mathrm{mg} / \mathrm{ml}$ of opsonized zymosan was obtained by dilution with PBS.

Preparation of Spleen Cell Suspension ${ }^{5}$ __ A male mouse of $\mathrm{C} 3 \mathrm{H}$ strain ( $7-8$ weeks) was killed by vertebral dislocation. The femoral vein was cut, and the spleen was extirpated after exsanguination. After being washed with Eagle's minimum essential medium (MEM), the spleen was sufficiently untangled and passed through an 80 mesh stainless steel sieve. Cells were collected by centrifugation at $1200 \mathrm{rpm}$ for $10 \mathrm{~min}$, then $2 \mathrm{ml}$ of 10 -fold dilution of Eagle's MEM was added. Immediately after hypotonic elimination of erythrocytes mixed therein for $10 \mathrm{~s}, 2 \mathrm{ml}$ of Eagle's MEM at 2-fold concentration was added and mixed. The cells were collected by centrifugation at $1200 \mathrm{rpm}$ for $10 \mathrm{~min}$, and diluted with RPMI-1640 medium to $1 \times 10^{7} \mathrm{cells} / \mathrm{ml}$. This was used as the whole spleen cell suspension. An aliquot was incubated for $60 \mathrm{~min}$ in a Petri dish of $5 \mathrm{~cm}$ in diameter. Non-adherent cells were collected and adjusted to $1 \times 10^{7}$ cells $/ \mathrm{ml}$ with RPMI-1640 medium. This was used as non-adherent spleen cell suspension.

Elimination of T Cells ${ }^{6)} \_$Non-adherent spleen cell suspension $(1 \mathrm{ml})$ obtained from male $\mathrm{C} 3 \mathrm{H}$ mice $(9$ weeks) was mixed with $20 \mu \mathrm{l}$ of $5 \%$ Thy-1.2 F7D5 monoclonal immunoglobulin M (IgM) cytotoxic antibody (Serotec Ltd., England), incubated for $30 \mathrm{~min}$, and washed once with RPMI-1640 medium. Then, $1 \mathrm{ml}$ of RPMI-1640 medium with fetal bovine serum containing 5\% guinea-pig complement was added and the whole was further incubated for $30 \mathrm{~min}$. The cells that reacted with antibody were selectively destroyed. The remaining cells were centrifuged at $1200 \mathrm{rpm}$ for $10 \mathrm{~min}$ and adjusted to $1 \times 10^{7}$ cells $/ \mathrm{ml}$.

Labeling of Target Cells ${ }^{7}$ ____ After being washed with RPMI-1640 medium, P-815 tumor cells were adjusted to $1 \times 10^{6}$ cells $/ \mathrm{ml}$. Then $25 \mu \mathrm{l}$ of ${ }^{3} \mathrm{H}$-uridine solution $(40 \mu \mathrm{Ci} / \mathrm{ml})$ was added to $1 \mathrm{ml}$ of the cell suspension, and the mixture was incubated for $54 \mathrm{~min}$, then centrifuged at $1200 \mathrm{rpm}$ for $10 \mathrm{~min}$. The cells were washed with RPMI-1640 medium and adjusted to $2 \times 10^{5}$ cells $/ \mathrm{ml}\left(1.0 \times 10^{5}-2.1 \times 10^{5} \mathrm{dpm} / 1 \times 10^{6}\right.$ cells $)$.

Cytotoxicity $^{7}$ __- The labeled target cell suspension $\left(1 \mathrm{ml} ; 2 \times 10^{5}\right.$ cells $\left./ \mathrm{ml}\right)$ was mixed with $1 \mathrm{ml}$ of the lymphocyte suspension $\left(1 \times 10^{7}\right.$ cells $\left./ \mathrm{ml}\right)$ prepared as described previously. $\left.{ }^{8}\right)$ Portions of $0.5 \mathrm{ml}$ each were incubated for $4 \mathrm{~h}$, then $0.4 \mathrm{ml}$ was dropped on a Millipore filter $(0.45 \mathrm{~nm}$ in pore size $)$ and suction-filtered. The filter was washed with $15 \mathrm{ml}$ of ice-cold $5 \%$ trichloroacetic acid (TCA) solution, dried and mixed with $10 \mathrm{ml}$ of lipophilic scintillator $(5 \mathrm{~g}$ of 2,5-diphenyloxazole (PPO), $0.3 \mathrm{~g}$ of 1,4-bis[2-(4-methyl-5-phenyloxazolyl)]benzene (DMPOPOP), and $1000 \mathrm{ml}$ of toluene). Radioactivity was measured with an Aloka LSC-700 scintillation counter. The cytotoxicity $(P)$ was calculated according to the following formula:

$$
P(\%)=\left(1-\frac{\mathrm{dpm} \text { with immunolymphocytes }- \text { background } \mathrm{dpm}}{\mathrm{dpm} \text { when target cells only were incubated }- \text { background } \mathrm{dpm}}\right) \times 100
$$

Preparation of Medium Containing Interleukin-1 (IL-1) ${ }^{91}$ - - Male mice of C3H strain (7 weeks) were given $50 \mu \mathrm{g} / \mathrm{d}$ of As-I i.p. for $5 \mathrm{~d}$. On the 5 th day, after the final dose, $\mathrm{M} \phi$ were collected and adjusted to $1 \times 10^{6}$ cells $/ \mathrm{ml}$. Aliquots of $0.4 \mathrm{ml}$ were placed on 24-well plates, and incubated for $60 \mathrm{~min}$. The plates were washed with RPMI-1640 medium, $0.4 \mathrm{ml}$ of RPMI-1640 medium without fetal bovine serum was added, and the plates were incubated for $72 \mathrm{~h}$. The supernatant was passed through a $0.45 \mu \mathrm{m}$ Millipore filter for sterilization, and preserved at $-80 \mathrm{C}$.

Measurement of Lymphocyte Growth Reaction ${ }^{9}$ __-Male $\mathrm{C} 3 \mathrm{H}$ mice (7 weeks) were killed by vertebral dislocation and bled from the femoral vein, then the thymus was extirpated. It was untangled in the Eagle's MEM, then passed through an 80-mesh stainless steel sieve, and a cell suspension was prepared. After adjustment to $1.5 \times 10^{7}$ cells/ml with RPMI-1640 medium containing $25 \mu \mathrm{M}$ 2-mercaptoethanol, it divided into $0.1 \mathrm{ml}$ aliquots on a 96-well plate (Corning Glass Works). Then, $0.05 \mathrm{ml}$ of $\mathrm{M} \phi$ supernatant (see preceding section) and $0.05 \mathrm{ml}$ of RPMI-1640 medium or $0.05 \mathrm{ml}$ of PHA-P at $10 \mu \mathrm{g} / \mathrm{ml}$ were added, and the total volume of $0.2 \mathrm{ml}$ was incubated for $72 \mathrm{~h}$. At $6 \mathrm{~h}$ before the end of incubation, $0.5 \mu \mathrm{Ci}$ of $\left[\right.$ methyl $\left.{ }^{3} \mathrm{H}\right]$ thymidine was added, and mixed gently by shaking the plate. The reaction fluid was filtered through a glass-fiber filter, which was dried after being washed with $5 \%$ TCA solution. The radioactivity was measured with a liquid scintillation counter.

Preparation of Lymphokines ${ }^{10)} \_$The spleen of a mouse was untangled and the cells were suspended in $10 \mathrm{ml}$ of RPMI-1640 medium, to which $0.5 \mathrm{ml}$ of $100 \mu \mathrm{g} / \mathrm{ml}$ Concanavarin-A was added. The mixture was incubated at $37^{\circ} \mathrm{C}$ for $48 \mathrm{~h}$. After centrifugation the obtained supernatant was preserved at $-80^{\circ} \mathrm{C}$. It was used as the supernatant containing lymphokines.

Statistical Processing of the Experimental Data_ Student's $t$-test was used to evaluate the significance of differences between the control and As-I administration groups. 


\section{Results and Discussion}

As described in the previous paper, ${ }^{1}{ }^{\prime}$ the administration of As-I $(0.5 \mathrm{mg} / \mathrm{kg} / \mathrm{d})$ caused $50 \%$ inhibition of Sarcoma- 180 tumor growth. This inhibitory effect, however, might in part have derived from allograft rejection because of the difference of major histocompatibility antigen (MHA) between the tumor cells and host cells. Thus, in the present study, IMC carcinoma tumors in $\mathrm{CDF}_{1}$ mice and $\mathrm{MM}-46$ carcinoma tumors in $\mathrm{C} 3 \mathrm{H}$ mice were used as syngeneic tumor systems with the same MHA. As-I was injected i.p. at the daily dose of 0.1 or $0.5 \mathrm{mg} / \mathrm{kg}$ for $10 \mathrm{~d}$ and the inhibition of tumor growth was determined. As shown in Table I, As-I inhibited the growth of IMC carcinoma and MM-46 carcinoma by about $30.1-32.0 \%$ and $79.8-82.7 \%$, respectively. These results indicate that As-I potentiated the host immune

TAble I. Antitumor Activities of As-I on Syngeneic or Allogeneic Tumor

\begin{tabular}{cccc}
\hline \hline Mouse and tumor & $\begin{array}{c}\text { Dose } \\
(\mathrm{mg} / \mathrm{kg} / \mathrm{d})\end{array}$ & $\begin{array}{c}\text { Weight } \\
(\mathrm{g})\end{array}$ & $\begin{array}{c}\text { Inhibition ratio } \\
(\%)\end{array}$ \\
\hline ICR-Sarcoma-180 & Saline & $8.21 \pm 0.75$ & 0.0 \\
& 0.5 & $4.12 \pm 1.13^{a)}$ & 49.8 \\
CDF $_{1}$-IMC carcinoma & 0.1 & $6.58 \pm 0.83^{b)}$ & 20.2 \\
& Saline & $6.12 \pm 0.77$ & 0.0 \\
C3H-MM-46 carcinoma & 0.5 & $4.13 \pm 0.96^{b)}$ & 32.0 \\
& 0.1 & $4.21 \pm 1.22^{a)}$ & 30.1 \\
& Saline & $7.32 \pm 0.65$ & 0.0 \\
& 0.5 & $1.46 \pm 1.35^{a)}$ & 79.8 \\
\hline
\end{tabular}

$t$-Test: a) $p<0.05, b) p<0.01$.

TABlE II. Effect of As-I on Phagocytic Activity of ${ }^{3} \mathrm{H}$-Uridine-Labeled IMC Carcinoma Cells by Macrophages from $\mathrm{CDF}_{1}$ Mice

\begin{tabular}{|c|c|c|c|c|c|}
\hline \multirow{2}{*}{ Mouse and tumor } & \multirow{2}{*}{ Agent } & \multicolumn{2}{|c|}{ Incorporation $\left(\mathrm{dpm} / 10^{5} \mathrm{M} \phi\right)$} & \multicolumn{2}{|c|}{ Ratio } \\
\hline & & In vivo (a) & In vitro $(\mathrm{b})$ & (a) & (b) \\
\hline \multirow[t]{2}{*}{ Normal $\mathrm{CDF}_{1}$} & Saline & $560.0 \pm 63.6$ & $237.5 \pm 97.3$ & 1.00 & 1.00 \\
\hline & As-I & $351.2 \pm 75.4^{a)}$ & $219.3 \pm 74.7^{a)}$ & 0.62 & 0.92 \\
\hline \multirow[t]{2}{*}{ IMC-bearing $\mathrm{CDF}_{1}$} & Saline & $141.0 \pm 26.3$ & $83.7 \pm 13.1$ & 1.00 & 1.00 \\
\hline & As-I & $172.1 \pm 11.8^{b)}$ & $106.4 \pm 29.8^{a)}$ & 1.22 & 1.27 \\
\hline
\end{tabular}

$t$-Test: a) $p<0.05$, b) $p<0.01$.

Table III. Effect of As-I on Phagocytic Activity of ${ }^{3} \mathrm{H}$-Uridine-Labeled MM-46 Carcinoma Cells by Macrophages from $\mathrm{C} 3 \mathrm{H}$ Mice

\begin{tabular}{|c|c|c|c|c|c|}
\hline \multirow{2}{*}{ Mouse and tumor } & \multirow{2}{*}{ Agent } & \multicolumn{2}{|c|}{ Incorporation $\left(\mathrm{dpm} / 10^{5} \mathrm{M} \phi\right)$} & \multicolumn{2}{|c|}{ Ratio } \\
\hline & & In vivo (a) & In vitro $(\mathrm{b})$ & (a) & (b) \\
\hline \multirow[t]{2}{*}{ Normal C3H } & Saline & $143.7 \pm 24.2$ & $42.5 \pm 9.7$ & 1.00 & 1.00 \\
\hline & As-I & $185.5 \pm 21.5^{b)}$ & $71.8 \pm 7.3^{b)}$ & 1.29 & 1.69 \\
\hline \multirow[t]{2}{*}{ MM-46-bearing $\mathrm{C} 3 \mathrm{H}$} & Saline & $570.0 \pm 76.8$ & $160.9 \pm 25.1$ & 1.00 & 1.00 \\
\hline & As-I & $861.1 \pm 33.6^{b)}$ & $183.2 \pm 19.6^{a)}$ & 1.51 & 1.14 \\
\hline
\end{tabular}

$t$-Test: a) $p<0.05, b) p<0.01$. 
response regardless of allograft rejection.

Thus, to clarify the mechanism of tumor growth inhibition by As-I, its influence on the activation of $\mathrm{M} \phi$, natural killer cells and cytotoxic T cells (effectors of host-mediated tumor growth inhibition) was assessed.

In the previous paper, ${ }^{2)}$ the phagocytic activity of latex particles and spreading rate of $\mathrm{M} \phi$ were increased by the administration of As-1. However, phagocytosis of latex particle by $\mathrm{M} \phi$ is nonspecific phagocytic activity. Therefore, the effects of As-I on phagocytosis of syngeneic tumor cells were tested in vivo and in vitro. As shown in Table II, in the case of IMC tumor-bearing $\mathrm{CDF}_{1}$ mice, in which As-I administration gave only about $30 \%$ inhibition of tumor growth, the phagocytic activity of $\mathrm{M} \phi$ was increased about $1.2-1.3$ times by injection of As-I at $30 \mu \mathrm{g} / \mathrm{kg} / \mathrm{d}$ for $5 \mathrm{~d}$, compared with that of the tumor-bearing control group receiving saline. On the other hand, in syngeneic MM-46 tumor-bearing $\mathrm{C} 3 \mathrm{H}$ mice, in which As-I gave about $80 \%$ growth inhibition, phagocytic activity was increased about 1.5 times by As-I in vivo, compared with the control group. The results are given in Table III.

The effect of As-I on cytolytic activity against phagocytosed cells by $\mathbf{M} \phi$ was examined in syngeneic tumor-host systems. As shown in Table IV, in the IMC carcinoma tumor cell- $\mathrm{CDF}_{1}$ mouse system, which responded poorly to As-I, the activity was not increased by As-I administration in vivo or in vitro. As shown in Table $\mathrm{V}$, however, in the MM-46 carcinoma tumor cell- $\mathrm{C} 3 \mathrm{H}$ mouse system, the cytolytic activity against MM-46 cell was increased about 1.3 times by As-I when $\mathrm{M} \phi$ obtained from tumor-bearing mice were used. This increase was about 1.5-1.6 times when the $\mathrm{M} \phi$ obtained from normal mice were used.

These results indicate that As-I potentiates the phagocytolytic and cytolytic activity of $\mathrm{M} \phi$ against syngeneic tumor cells, and this suggests that the extent of inhibition of tumor growth by As-I may vary depending on the extent of potentiation. Since it was already clarified that $\mathrm{M} \phi$ were potentiated by As-I, we examined SOA release by $\mathrm{M} \phi$ in phagocytosis,

TABLE IV. Cytolytic Activity against IMC Carcinoma Cells by Macrophages from $\mathrm{CDF}_{1}$ Mice

\begin{tabular}{|c|c|c|c|c|c|}
\hline \multirow{2}{*}{ Mouse and tumor } & \multirow{2}{*}{ Agent } & \multicolumn{2}{|c|}{ Degradation (dpm/105 $\mathrm{M} \phi)$} & \multicolumn{2}{|c|}{ Ratio } \\
\hline & & In vivo (a) & In vitro $(\mathrm{b})$ & (a) & (b) \\
\hline \multirow[t]{2}{*}{ Normal $\mathrm{CDF}_{1}$} & Saline & $164.8 \pm 11.8$ & - & 1.00 & - \\
\hline & As-I & $181.2 \pm 34.1$ & - & 1.10 & - \\
\hline \multirow{2}{*}{ IMC-bearing $\mathrm{CDF}_{1}$} & Saline & $207.9 \pm 21.4$ & $81.5 \pm 18.2$ & 1.00 & 1.00 \\
\hline & As-I & $241.2 \pm 21.1^{a)}$ & $93.3 \pm 6.8^{a)}$ & 1.14 & 1.18 \\
\hline
\end{tabular}

$t$-Test: a) $p<0.05$.

TABle V. Cytolytic Activity against MM-64 Carcinoma Cells by Macrophages from $\mathrm{C} 3 \mathrm{H}$ Mice

\begin{tabular}{|c|c|c|c|c|c|}
\hline \multirow{2}{*}{ Mouse and tumor } & \multirow{2}{*}{ Agent } & \multicolumn{2}{|c|}{ Degradation $\left(\mathrm{dpm} / 10^{5} \mathrm{M} \phi\right)$} & \multicolumn{2}{|c|}{ Ratio } \\
\hline & & In vivo (a) & In vitro $(\mathrm{b})$ & (a) & (b) \\
\hline \multirow[t]{2}{*}{ Normal } & Saline & $257.3 \pm 21.3$ & $74.7 \pm 11.5$ & 1.00 & 1.00 \\
\hline & As-I & $419.4 \pm 12.1^{c)}$ & $109.1 \pm 10.1^{b)}$ & 1.63 & 1.46 \\
\hline \multirow[t]{2}{*}{ MM-46-bearing $\mathrm{C} 3 \mathrm{H}$} & Saline & $186: 2 \pm 9.7$ & $65.7 \pm 7.3$ & 1.00 & 1.00 \\
\hline & As-I & $247.6 \pm 18.4^{b)}$ & $83.2 \pm 11.6^{a)}$ & 1.33 & 1.28 \\
\hline
\end{tabular}

$t$-Test: $a$ ) $p<0.05, b) p<0.01, c) p<0.001$. 
as a parameter of cytotoxicity of activated $\mathrm{M} \phi .^{3)}$ Table VI shows the SOA release by $\mathrm{M} \phi$ obtained from $\mathrm{C} 3 \mathrm{H}$ mice injected i.p. with As-I $(30 \mu \mathrm{g} / \mathrm{d})$ for $5 \mathrm{~d}$ after MM-46 carcinoma tumor transplantation. SOA was released rapidly only during the first $90 \mathrm{~min}$ of phagocytosis in both the As-I group and the control group. Table VI shows the SOA released during the first 90 min after As-I administration, SOA production was increased about 1.2 times in $\mathrm{M} \phi$ obtained from normal mice. In general, immunity is lowered in tumor-bearing hosts. SOA production by $\mathrm{M} \phi$ obtained from MM-46 tumor-bearing mice decreased when saline was injected in place of As-I, but As-I restored the normal level, 1.2 times higher than that for $\mathrm{M} \phi$ from control mice. Next, $30 \mu \mathrm{g} / \mathrm{d}$ of As-I was injected for $5 \mathrm{~d}$ after grafting MM-46 carcinoma into $\mathrm{C} 3 \mathrm{H}$ mice, and SOA release from $\mathrm{M} \phi$ collected on the 7 th, 12 th and 18 th days after tumor implantation was measured. The results are given in Table VII.

While the SOA volume rapidly decreased in the control group, the decrease was comparatively less in the As-I group and tended to approach the level of normal mouse as time passed. Thus, the tumor growth inhibition may arise because As-I prevents deterioration of immune functions caused by the tumor-bearing state, or activates the cytotoxicity of $\mathrm{M} \phi$. Next, the effects of As-I on NK cells nonspecifically injuring tumor cells and Tc specifically

TABLE VI. Amount of SOA Released by Macrophages from $\mathrm{C} 3 \mathrm{H}$ Mice

\begin{tabular}{llrl}
\hline \hline Mouse and tumor & Agent & $\begin{array}{c}\text { SOA release } \\
(\mathrm{nmol} / \mathrm{mg} \text { protein })\end{array}$ & Ratio \\
\hline \multirow{2}{*}{ Normal C3H } & Saline & $10.64 \pm 2.11$ & 1.00 \\
& As-I & $12.91 \pm 1.37$ & $1.20^{a)}$ \\
MM-46-bearing C3H & Saline & $9.15 \pm 1.18$ & $0.86(1.00)$ \\
& As-I & $13.08 \pm 2.14$ & $1.23^{a)}(1.43)$ \\
\hline
\end{tabular}

$t$-Test: a) $p<0.05$.

TABLE VII. Time Course of SOA Release by Macrophages from MM-46-Bearing C3H Mice (in Vivo System)

\begin{tabular}{clcc}
\hline $\begin{array}{c}\text { Days after tumor } \\
\text { inoculation }\end{array}$ & Agent & $\begin{array}{c}\text { SOA release (A) } \\
(\mathrm{nmol} / \mathrm{mg} \text { protein })\end{array}$ & $\begin{array}{c}\text { Ratio } \\
\left(\mathrm{A} / \mathbf{B}^{\circ}\right)\end{array}$ \\
\hline \multirow{2}{*}{7} & Saline & $60.09 \pm 3.14$ & 0.83 \\
12 & As-I & $84.82 \pm 4.30$ & $1.17^{a)}$ \\
& Saline & $51.41 \pm 0.93$ & 0.71 \\
18 & As-I & $71.68 \pm 1.17$ & 0.99 \\
& Saline & $38.38 \pm 2.83$ & 0.53 \\
& As-I & $68.06 \pm 3.37$ & $0.96^{a)}$ \\
\hline
\end{tabular}

B : normal C3H mice $72.41 \pm 2.83(t$-test: $a) p<0.05)$.

TABlE VIII. Effect of As-I on NK Activity of Non-adherent Spleen Lymphocytes against YAC-1 Tumor Cells

\begin{tabular}{lcc}
\hline \hline Agent & $\begin{array}{c}\text { NK activity (\%) } \\
\text { (Relative cytotoxicity) }\end{array}$ & Ratio \\
\hline Saline & $4.71 \pm 1.09$ & 1.00 \\
As-I & $8.10 \pm 0.87^{a)}$ & 1.72 \\
\hline
\end{tabular}


injuring only the antigen-presenting cells were studied. The effects of As-I on NK cells indicated by interferon from pre-NK cells were assessed by measuring the activity in spleen cell using, as target cells, YAC-1 and P-815 tumor cells labelled with ${ }^{3} \mathrm{H}$-uridine.

As-I $(30 \mu \mathrm{g} / \mathrm{d})$ was given for $3 \mathrm{~d}$ to $\mathrm{C} 3 \mathrm{H}$ mice, and the non-adherent extirpated spleen. The cytotoxic activity against YAC-1 tumor cells (believed to be most susceptible to NK cells) was measured. As shown in Table VIII, the cytotoxicity was potentiated about 1.7 times by As-I administration.

After transplantation of MM-46 tumor cells into $\mathrm{C} 3 \mathrm{H}$ mice, $30 \mu \mathrm{g} / \mathrm{d}$ of As-I was administered for $3 \mathrm{~d}$ and the spleen was extirpated after the periods indicated. Cytotoxic activity of the non-adherent spleen cell suspension against P-815 tumor cells was measured. As shown in Table IX, the activity was potentiated about 1.7 times on the 7 th day after completion of the treatment, but the increase was only 1.15 times on the 9 th day.

The cytotoxicity in tumor-bearing mice dosed with As-I may be due in part to lymphokine-activated killer cells (LAK), but the whole cytotoxic activity including both NK and LAK was taken as activity of NK cells in this experiment.

Next, the effect of As-I in vitro was examined, and the results are shown in Table X. After a $48 \mathrm{~h}$ incubation with $5 \mu \mathrm{g} / \mathrm{ml}$ of As-I, cytotoxic activity against P-815 tumor cells was measured. The cell suspension prepared from the spleen of MM-46 tumor-bearing mice on the 6th day of saline administration showed 0.9 times the cytotoxic activity of the control, but when As-I was injected, the activity was increased to 1.3 times the control. The potentiation was nullified $9 \mathrm{~d}$ after tumor implantation. These results suggest that As-I may potentiate the cytotoxicity of NK cells directly or may accelerate the differentiation of inactive pre-NK cells to active NK cells. Such activity has been reported in a muramic acid derivative (N-CWS)

TABLE IX. Effect of As-I on NK Activity of Non-adherent Spleen Lymphocytes in Relation to the Timing of Administration (in Vivo) to Tumor-Bearing Mice

\begin{tabular}{clcc}
\hline \hline $\begin{array}{c}\text { Days after As-I } \\
\text { administration }\end{array}$ & Agent & $\begin{array}{c}\text { NK activity }(\%) \\
\text { (Relative cytotoxicity) }\end{array}$ & Ratio \\
\hline \multirow{2}{*}{3} & Saline & $8.08 \pm 3.57$ & 1.00 \\
& As-I & $9.59 \pm 0.84^{a)}$ & 1.19 \\
5 & Saline & $9.13 \pm 1.18$ & 1.00 \\
& As-I & $11.29 \pm 0.34^{b)}$ & 1.24 \\
7 & Saline & $7.47 \pm 2.14$ & 1.00 \\
& As-I & $12.81 \pm 0.65^{b)}$ & 1.71 \\
& Saline & $8.83 \pm 0.97$ & 1.15 \\
\hline
\end{tabular}

$t$-Test: a) $p<0.05, b) p<0.01$.

TABLE X. Effect of As-I on NK Activity of Non-adherent Spleen Lymphocytes (in Vivo) from $\mathrm{C} 3 \mathrm{H}$ Mice

\begin{tabular}{llll}
\hline \hline \multirow{2}{*}{ Mouse and tumor } & Agent & \multicolumn{2}{c}{$\begin{array}{c}\text { NK activity (ratio) } \\
\text { (Relative cytotoxicity) }\end{array}$} \\
\cline { 3 - 4 } & & $6 \mathrm{~d}$ & $9 \mathrm{~d}$ \\
\hline \multirow{2}{*}{ Normal mice } & Saline & 1.00 & 1.00 \\
& As-I & 1.06 & 0.95 \\
MM-46-bearing mice & Saline & 0.89 & 1.03 \\
& As-I & 1.33 & 1.11 \\
\hline
\end{tabular}


TABLE XI. Effect of As-I on the Development of Alloreactive Cytotoxic T-Lymphocytes

\begin{tabular}{clccc}
\hline \hline Agent & Treatment (in vivo) & Cytolysis (\%) & \multicolumn{2}{c}{ Ratio } \\
\hline \multirow{2}{*}{ Saline } & Non & $21.07 \pm 1.83$ & 1.00 & 1.00 \\
& Anti-Thy $1.2+\mathrm{C}^{\prime}$ & $8.39 \pm 0.91$ & 0.40 & \\
\multirow{2}{*}{ As-I } & Non & $27.07 \pm 0.74^{a)}$ & 1.00 & 1.28 \\
& Anti-Thy $1.2+\mathrm{C}^{\prime}$ & $14.31 \pm 1.14^{a}$ & 0.53 & \\
\hline
\end{tabular}

$t$-Test: a) $p<0.05$.

isolated from the cell walls of actinomyces by Saijo et al.,${ }^{5)}$ and in lentinan obtained from shiitake by Herberman et al. ${ }^{11)}$

Some structurally related $\beta$-glucans extracted from Basidiomycetes spp. (including lentinan) potentiate the induction of $\mathrm{T}$ cells $(\mathrm{Tc}){ }^{12)}$ Accordingly, the effect of As-I was examined, and the results are given in Table XI. After sensitization by i.p. inoculation of P815 tumor cells as antigen cells into $\mathrm{C} 3 \mathrm{H}$ mice, $30 \mu \mathrm{g} / \mathrm{d}$ of As-I was injected for $3 \mathrm{~d}$. On the 9 th day, whole spleen cell suspension was obtained from the spleen. The cytotoxic activity of this cell fraction was about 1.3 times that of mice given saline in place of As-I. When T cells were excluded from this cell suspension by treatment with anti-Thy 1.2 F7D5 monoclonal IgM cytotoxic antibody and complement, the cytotoxic activity was almost halved. This suggests that the cytotoxicity potentiated by As-I administration is derived from T cells. That is, As-I accelerated the induction of Tc. For such induction of Tc, in addition to antigen cells and precursors of T cells, IL-1 produced by activated M $\phi$ and IL-2 produced by helper T cells stimulated by IL-1 are required.

Rosenberg et al. ${ }^{13)}$ succeeded in inducing Tc injuring NK-resistant tumor cells by processing mouse spleen cells with IL-2. As-I is able to activate $\mathrm{M} \phi$ in vivo and in vitro. Therefore, it is considered that As-I activates the production of IL-1 by $\mathrm{M} \phi$ and subsequently the production of IL-2 from helper Tc, thus accelerating the induction of Tc.

In brief, As-I, a $\beta$-1,3-glucan isolated from mycelia of Cochliobolus miyabeanus (Ascomycetes), inhibited the growth of syngeneic tumors in mice. It not only caused direct activation of various effector cells to attack tumor cells, but also inhibited the secondary deterioration of immune function in the tumor-bearing hosts. Similar actions have been reported by $\beta$-glucans extracted from fruit bodies of Basidiomycetes, but this is the first report concerning a glucan from Ascomycetes. The action of As-I on lymphokines and IL-1 remains to be elucidated.

\section{References}

1) H. Nanba and H. Kuroda, Chem. Pharm. Bull., 35, 1285 (1987).

2) H. Nanba and H. Kuroda, Chem. Pharm. Bull., 35, 1289 (1987).

3) M. Ito, H. Suzuki, N. Nakano, N. Yamashita, E. Sugiyama, M. Maruyama, K. Hoshino and S. Yana, Jpn. J. Cancer Res. (Gann), 74, 128 (1983).

4) R. B. Johnston, B. B. Keele, H. P. Misra, J. E. Lehmeyer, L. S. Webb, R. L. Baehner and K. V. Rajagopalan, J. Clin. Invest., 55, 1357 (1975).

5) N. Saijo, A. Ozaki, Y. Beppu, N. Irimajiri, N. Shibuya, E. Shimizu, T. Takizawa, T. Taniguchi and A. Hoshi, Jpn. J. Cancer Res. (Gann), 74, 137 (1983).

6) H. Nakajima, S. Abe, Y. Masuko, J. Tsubouchi, M. Yamazaki and D. Mizuno, Jpn. J. Cancer Res. (Gann), 72, 723 (1981).

7) K. Hashimoto and T. Kitagawa, Cell Antigen, 4, 352 (1972).

8) K. Adachi, H. Nanba and H. Kuroda, Chem. Pharm. Bull., 35, 262 (1987).

9) H. Nakajima, Y. Kita, T. Takashi, M. Akasaki, F. Yamaguchi, S. Ozawa, W. Tsukada, S. Abe and D. Mizuno, Jpn. J. Cancer Res. (Gann), 75, 260 (1984). 
10) M. S. Meltzer and J. J. Oppenheim, J. Immunol., 8, 77 (1977).

11) R. B. Herberman, J. Y. Djeu, H. D. Kay, J. R. Ortaldo, C. Riccardi, G. D. Bonnard, H. T. Holden, R. Fargnani, A. Santoni and P. Pucetti, Immunol. Rev., 44, 43 (1979).

12) J. Hamuro, H. Wagner and M. Rollinghoff, Cell Immunol., 38, 328 (1978).

13) M. Rosenstein, I. Yron, Y. Kaufmann and S. A. Rosenberg, Cancer Res., 44, 1946 (1978). 